\title{
STRUCTURAL TRANSFORMATION OF 2:1 DIOCTAHEDRAL LAYER SILICATES DURING DEHYDROXYLATION-REHYDROXYLATION REACTIONS
}

\author{
Fabrice Muller, Victor Drits,' Alain Plançon, and Jean-Louis Robert \\ ISTO, CNRS-University of Orléans, 1A rue de la Férollerie, 45071 Orléans, Cedex 2, France \\ ${ }^{I}$ Geological Institute of the Russian Academy of Sciences, Pyzhevsky per.7, Moscow, Russia
}

\begin{abstract}
The structural transformation of dioctahedral 2:1 layer silicates (illite, montmorillonite, glauconite, and celadonite) during a dehydoxylation-rehydroxylation process has been studied by $\mathrm{X}$-ray diffraction, thermal analysis. and infrared spectroscopy. The layers of the samples differ in the distribution of the octahedral cations over the cis- and trans-sites as determined by the analysis of the positions and intensities of the $11 \mathrm{l}, 02 \mathrm{l}$ reflections, and that of the relative displacements of adjacent layers along the $a$ axis $(c \cos \beta / a)$, as well as by dehydroxylation-temperature values. One illite, glauconite, and celadonite consist of trans-vacant $(t v)$ layers; Wyoming montmorillonite is composed of $c i s$-vacant ( $c v$ ) layers, whereas in the other illite sample $N$ and $c v$ layers are interstratified. The results obtained show that the rehydroxylated Al-rich minerals (montmorillonite, illites) consist of $t v$ layers whatever the distribution of octahedral cations over cis-and trans-sites in the original structure. The reason for this is that in the dehydroxylated state, both $t v$ and $c v$ layers are transformed into the same layer structure where the former trans-sites are vacant.

The dehydroxylation of glauconite and celadonite is accompanied by a migration of the octahedral cations from former cis-octahedra to empty trans-sites. The stnuctural transformation of these minerals during rehydroxylation depends probably on their cation composition. The rehydroxylation of celadonite preserves the octahedral-cation distribution formed after dehydroxylation. Therefore, most 2:1 layers of celadonite that rehydroxylate $(\sim 75 \%)$ have cis-vacant octahedra and, only in a minor part of the layers, a reverse cation migration from former trans-sites to empty octahedra occurred. In contrast, for a glauconite sample with a high content in ${ }^{\mathrm{IV}} \mathrm{Al}$ and ${ }^{\mathrm{V}} \mathrm{Al}$ the rehydroxylation is accompanied by the reverse cation migration and most of the 2:1 layers are transformed into $t v$ layers.
\end{abstract}

Key Words - Cation Migration, Celadonite, Cis-Vacant Octahedra, Dehydroxylation, Glauconite, Illite, Rehydroxylation, Smectites, Structure, Trans-Vacant Octahedra.

\section{INTRODUCTION}

The study of clay minerals by thermal analysis has a long history during which a rich empirical material has been collected. Dioctahedral smectites and finely dispersed micas are characterized by a wide range of dehydroxylation temperatures (Brindley, 1976; Grim et al., 1951; Grim, 1968; Guggenheim, 1990; Guggenheim and Koster van Gross, 1992; Heller-Kallai et al., 1962; Koster van Gross and Guggenheim, 1987, 1990; Mackenzie, 1957, 1982; Tsipursky et al., 1985). It is also remarkable that these dehydroxylated minerals can regain $\mathrm{OH}$ groups after heating in water vapor (Mackenzie, 1957; Grim, 1968).

The most reliable structural results have been obtained for aluminous minerals. Wardle and Brindley (1972) and Udagawa et al. (1974) determined the dehydroxylated structure for powdered pyrophyllite and muscovite. Pyrophyllite and muscovite consist of trans-vacant $(t v)$ 2:1 layers. Their dehydroxylated structures are similar to their original form, but contain five-coordinated $\mathrm{Al}$ cations instead of six-coordinated ones.

Guggenheim et al. (1987), Koster van Gross and Guggenheim (1987, 1990), and Guggenheim (1990) used a detailed crystallo-chemical approach to consid- er the dynamics of the dehydroxylation process of aluminous dioctahedral 2:1 layer silicates assuming that montmorillonites, beidellites, and illites have the same structure of 2:1 layers as pyrophyllite and muscovite. However, it has been found by oblique-texture electron diffraction and the simulation of X-ray diffraction (XRD) patterns that most montmorillonites as well as some illites and interstratified illite-smectites (I-S) are $c i s$-vacant $(c v)$ or have coexistence of $t v$ and $c v$ layers (Tsipursky and Drits, 1984; Zvyagin et al., 1985; Drits et al., 1996, 1998; Reynolds and Thompson, 1993; McCarty and Reynolds, 1995; Cuadros and Altaner, 1998). The derivative thermal gravimetric (DTG) curves of most montmorillonites have one endothermic peak near $700^{\circ} \mathrm{C}$ whereas beidellites and illites dehydroxylate near $550^{\circ} \mathrm{C}$. I-S are often characterized by two endothermic reactions near 500 and $700^{\circ} \mathrm{C}$ (Mackenzie, 1957; Grim, 1968). In $c v$ layers the OH$\mathrm{OH}$ edge is not shared and thus $\mathrm{OH}-\mathrm{OH}$ forms a common edge to occupied and vacant $c i s$-octahedra. The $\mathrm{OH}-\mathrm{OH}$ edge length is considerably longer than the length of the shared $\mathrm{OH}-\mathrm{OH}$ edge of $t v$ layers. Drits et al. (1995) assumed that thermal energy needed for a proton to jump to the nearest $\mathrm{OH}$ group to form a water molecule strongly depends on the distance be- 
tween the nearest $\mathrm{OH}$ groups. Therefore $c v$ montmorillonite requires a higher dehydroxylation energy than $t v$ illite because of the longer $\mathrm{OH}-\mathrm{OH}$ distance. These authors also showed that, contrary to $t v$ layers, the dehydroxylation of $c v$ aluminous 2:1 layers occurs in two stages. During the first stage the adjacent $\mathrm{OH}$ groups are replaced by a single residual oxygen atom, $\mathrm{O}_{\mathrm{r}}$, and the Al cations, which originally occupied cisand trans-sites become, respectively, five- and six-coordinated. During the second stage, the Al cations migrate from the former trans-sites to vacant pentagonal prisms. As a result, the dehydroxylated structures of the former $c v$ and $t v$ aluminous layers are similar.

Concerning the dehydroxylation of $\mathrm{Fe}^{3+}$-rich dioctahedral 2:1 phyllosilicates (glauconites, celadonites, and nontronites), there are two contradictory interpretations. Heller-Kallai and Rozenson (1980) and Rozenson and Heller-Kallai (1980) concluded that there is no cation migration during dehydroxylation whatever the cation composition. They assumed that in $\mathrm{Fe}^{3+}$-rich 2:1 phyllosilicates, $\mathrm{Fe}^{3+}$ occupies both cis- and transoctahedra. However, the structural study of nontronites, glauconites, and celadonites by diffraction methods has shown that these minerals always consist of tv 2:1 layers (Tsipursky and Drits, 1984, Sakharov et al., 1990, Drits et al., 1997, Manceau et al., 2000). In addition, Tsipursky et al. (1985) showed that octahedral cations migrate from cis- to trans-sites in the dehydroxylated $\mathrm{Fe}^{3-}$-rich dioctahedral 2:1 layer silicates, assuming that, as in the case of the aluminous varieties, $\mathrm{O}_{\mathrm{r}}$ locates midway between two closest $\mathrm{Fe}^{3+}$ with the same $z$ coordinate. As a result, $\mathrm{Fe}^{3+}$ cations, which formerly occupied the cis-sites, become six-coordinated after migration. Muller et al. (2000) studied the dehydroxylation process of several Fe-rich minerals using XRD. The diffraction patterns were simulated using the CALCIPOW computer program designed for the simulation of the intensities diffracted by layer structures containing different kinds of layers and stacking faults (Plançon, 1981). Several models were calculated, differing by the site occupancies and location of residual oxygen anions. An occupancy of the former vacant trans-sites and the location of the residual oxygens in one of the two possible positions of the former $\mathrm{OH}$ groups yields the best fit between experimental and calculated patterns, confirming the migration of $\mathrm{Fe}^{3-}$ cations for the dehydroxylated celadonites and glauconites. The $\mathrm{Fe}^{3+}$ cations in the former trans- and cis-sites preserve their five-coordination and the location of the residual anions provides structural stability for glauconite and celadonite dehydroxylates.

In contrast to the study of dehydroxylation reactions, there are only a few studies devoted to the rehydration of dehydroxylated dioctahedral 2:1 phyllosilicates having different original structure and composition (Mackenzie, 1957; Grim, 1968; Emmerich et al., 1999). Montmorillonites with an endothermic peak near $700^{\circ} \mathrm{C}$ can regain their initial hydroxyls by cooling in the presence of water vapor. However, the DTG curves of these rehydroxylated montmorillonites have either one peak near $600^{\circ} \mathrm{C}$ or two peaks near 500 and $650^{\circ} \mathrm{C}$, respectively. Dehydroxylated beidellites and illites can also be rehydroxylated. In this case, the loss of hydroxyls of the rehydroxylated samples in DTG analysis occurs at temperatures near the dehydroxylation temperature of the original samples. An explanation to the difference in thermal behavior of rehydroxylated montmorillonites and rehydroxylated beidellites and illites was proposed by Drits et al. (1995) where they suggested that original $c v$ montmorillonites can be transformed into $t v$ rehydroxylates. This hypothesis was confirmed experimentally for smectites (Emmerich et al., 1999), but not for illites. The structure of rehydroxylated Fe-rich dioctahedral 2:1 layer silicates has not been examined.

In this paper, XRD, DTG analysis, and infrared (IR) spectroscopy was used to study natural (N), dehydroxylated (D), rehydoxylated (R), and de-rehydroxylated (DR) dioctahedral 2:1 clay minerals consisting of $t v$ and $c v$ or interstratified $t v / c v$ layers of different cation compositions. The fundamental method for the study of the polymorphous transformation of $c v$ layers into tv layers (or vice versa) is XRD. Thermal gravimetric (TG) analysis and IR were used to complement the interpretation of the XRD data.

\section{EXPERIMENTAL}

Two illites (identified below as $t v$ and $c v / t v$ ), a Wyoming montmorillonite, a glauconite, and a celadonite were studied. Structural formulae and references where these samples are described are presented in Table 1.

Powder XRD patterns were recorded using MoK $\alpha$ radiation with an INEL CPS 120 diffractometer equipped with a curved position-sensitive detector. This detector permits a simultaneous recording of the XRD pattern in a $2 \theta$ interval from 6 to $30^{\circ}$. The sample holder was a Lindemann glass tube with a $1-\mathrm{mm}$ diameter. The diffusion background arising from the empty tube was subtracted in the experimental XRD patterns.

The unit-cell parameters were determined by using the following procedure. The values of $b$ were determined by measuring $d(060)$ values. For mica samples, the positions of 003 reflections permitted the determination of the $d(001)=c \sin \beta$ values, whereas the $11 \overline{2}$ and 112 reflections were used to estimate $a$ and $\beta$ using well-known relationships between $h k l$ indices, $d(h k l)$, and the monoclinic unit-cell parameters (Sakharov et al., 1990; Muller et al., 2000). This procedure provides an accurate determination of the $a$ and $\beta$ parameters if the sample consists of identical 2:1 layers (either $t v$ and $c v$ ). The interstratification of $c v$ and $t v$ 
Table 1. Structural formula of samples under study calculated per $\mathrm{O}_{10}(\mathrm{OH})_{2}$.

\begin{tabular}{|c|c|c|c|c|c|c|}
\hline & & $\begin{array}{c}\text { Illite } \\
\text { (sample } 60 \text { ) }\end{array}$ & $\begin{array}{l}c w / t \\
\text { illite }\end{array}$ & $\begin{array}{c}\text { Wyoming } \\
\text { montmorillonite }\end{array}$ & $\begin{array}{c}\text { Glauconite } \\
\text { (sample 6869) }\end{array}$ & $\begin{array}{l}\text { Celadonite } \\
\text { (sample 69) }\end{array}$ \\
\hline \multirow[t]{2}{*}{ Tetrahedral cations } & $\mathrm{Si}$ & 3.63 & 3,47 & 3.96 & 3.78 & 3.94 \\
\hline & Al & 0.37 & 0.53 & 0.04 & 0.22 & 0.06 \\
\hline \multirow[t]{5}{*}{ Octahedral cations } & $\mathrm{Al}$ & 1.41 & 1.71 & 1.53 & 0.55 & 0.05 \\
\hline & $\mathrm{Fe}^{3-}$ & 0.10 & 0.04 & 0.18 & 0.89 & 1.15 \\
\hline & $\mathrm{Fe}^{2-}$ & 0.07 & - & & 0.18 & 0.36 \\
\hline & $\mathrm{Mg}$ & 0.42 & 0.26 & 0.26 & 0.39 & 0.41 \\
\hline & $\mathrm{Ti}$ & - & 0.01 & 0.01 & - & \\
\hline \multirow[t]{3}{*}{ Interlayer cations } & $\mathrm{K}$ & 0.77 & 0.63 & & 0.80 & 0.83 \\
\hline & $\mathrm{Na}$ & 0.07 & 0.07 & 0.35 & - & 0.01 \\
\hline & $\mathrm{Ca}$ & 0.01 & 0.07 & & - & 0.03 \\
\hline
\end{tabular}

${ }^{1}$ Ivanovskaya et al. (1989).

${ }^{2}$ Horton (1983).

${ }^{\mathrm{c}}$ Private communication of R. Glaeser.

4,5 Drits et al. (1997).

layers induces a displacement of the $11 l$ reflections from the positions corresponding to periodic $t v$ and $c v$ dioctahedral micas, in which case the $a$ and $\beta$ values determined by this procedure do not correspond to the actual parameters. The criteria described by Drits and McCarty (1996) which use experimental $d(11 l)$, $d(00 l), d(060)$, and calculated $c \cos \beta / a$ values have been applied to distinguish $c v, t v$, and interstratified $c v / t v$ mica structures. Errors in determination of the $d(h k l)$ values do not exceed $0.002 \AA$.

The natural samples were heated to $650^{\circ} \mathrm{C}$ (glauconite and celadonite) or $750^{\circ} \mathrm{C}$ (illites and montmorillonite) for dehydroxylation. The heating rate was $100^{\circ} \mathrm{C} / \mathrm{h}$, each sample remaining heated at the upper temperature for $1 \mathrm{~h}$, and then cooled in air. To rehydroxylate samples, gold capsules were filled with the dehydroxylate plus $20 \mathrm{wt} \%$ water. The capsules were placed in a Tuttle-type pressure vessel at $400^{\circ} \mathrm{C}$ and 1 $\mathrm{kbar}$ for $10 \mathrm{~d}$. After removal from the pressure vessel, the rehydroxylated samples were heated at $120^{\circ} \mathrm{C}$ for several hours to dry the sample.

Thermal gravimetric analyses were performed with a Setaram TGA 92 microanalyser, with a heating rate of $10^{\circ} \mathrm{C} / \mathrm{min}$. A $30-\mathrm{mg}$ sample was used for each measurement. The derivatives of the TG curves (DTG) compare the weight loss, which was assigned to water evolved from hydroxyl groups.

IR spectra in the OH-stretching region were obtained with a Perkin Elmer Paragon 1000PC spectrometer. A 3-mg sample (except for glauconite: $0.5 \mathrm{mg}$ ) was mixed with $150 \mathrm{mg}$ of $\mathrm{KBr}$ in a steel capsule $(0.5$ $\mathrm{mg}$ only for $c v / t v$ illite). The disk obtained after pressing was heated at $140^{\circ} \mathrm{C}$ for $15 \mathrm{~h}$ to remove most of the absorbed water. The transmitted intensities were recorded from 3000 to $4000 \mathrm{~cm}^{-1}$ at $1-\mathrm{cm}^{-1}$ intervals.

\section{RESULTS}

Figure 1 shows the XRD patterns obtained for the four states $(N, D, R, D R)$ of the five studied samples. Table 2 provides the unit-cell parameters of these sam- ples and the $c \cos \beta / a$ value which characterizes the relative displacement of the adjacent layers along the $a$ axis. Wyoming montmorillonite has a turbostratic structure. Therefore, the determination of its unit-cell parameters is limited to $d(001)$ and $b ; a$ is taken as $b /$ $\sqrt{3}$. Figure 2 compares the TG and DTG curves of the original and rehydroxylated samples. Figure 3 shows the IR spectra of the original and rehydroxylated samples in the stretching-vibration region. The wavenumbers corresponding to the centers of the complex $\mathrm{OH}$-stretching bands are shown at each transmittance minimum.

\section{tv illite (sample 60)}

The XRD patterns and unit-cell parameters (Figure 1a; Table 2) of the $\mathrm{N}$ and $\mathrm{R}$ specimens reflect the diffraction and structural characteristics of dioctahedral tv $1 M$ mica, i.e., strong $11 \overline{1}, 11 \overline{2}$, and 112 reflections, almost zero intensity of the 111 reflection, and relative displacements of adjacent layers along the $a$ axis between -0.39 and -0.40 (Bailey, 1984; Drits et al., 1984a, 1993). The XRD patterns for the D and DR forms are quite similar and preserve the main diffraction features of the $N$ and $R$ samples (Table 2). Thus, the XRD data show that there is no octahedral-cation migration. In all states the trans-octahedral sites remain vacant.

This conclusion is consistent with the DTG curve (Figure 2a). The shift in peaks of the maximum water lost in $\mathrm{N}\left(600^{\circ} \mathrm{C}\right)$ and $\mathrm{R}\left(575^{\circ} \mathrm{C}\right)$ is probably related to a partial decrease in the particle size after dehydroxylation. The IR spectra of the $\mathrm{N}$ and $\mathrm{R}$ specimens are very similar (Figure 3a). The center of the $\mathrm{OH}$-stretching band of $\mathrm{N}\left(3606 \mathrm{~cm}^{-1}\right)$ shifts to higher frequencies for $R\left(3621 \mathrm{~cm}^{-1}\right)$.

\section{cv/tv illite}

This sample, described by Horton (1983) as $3 T$ illite, was found among clay minerals associated with a hydrothermal ore vein. Reynolds and Thompson 

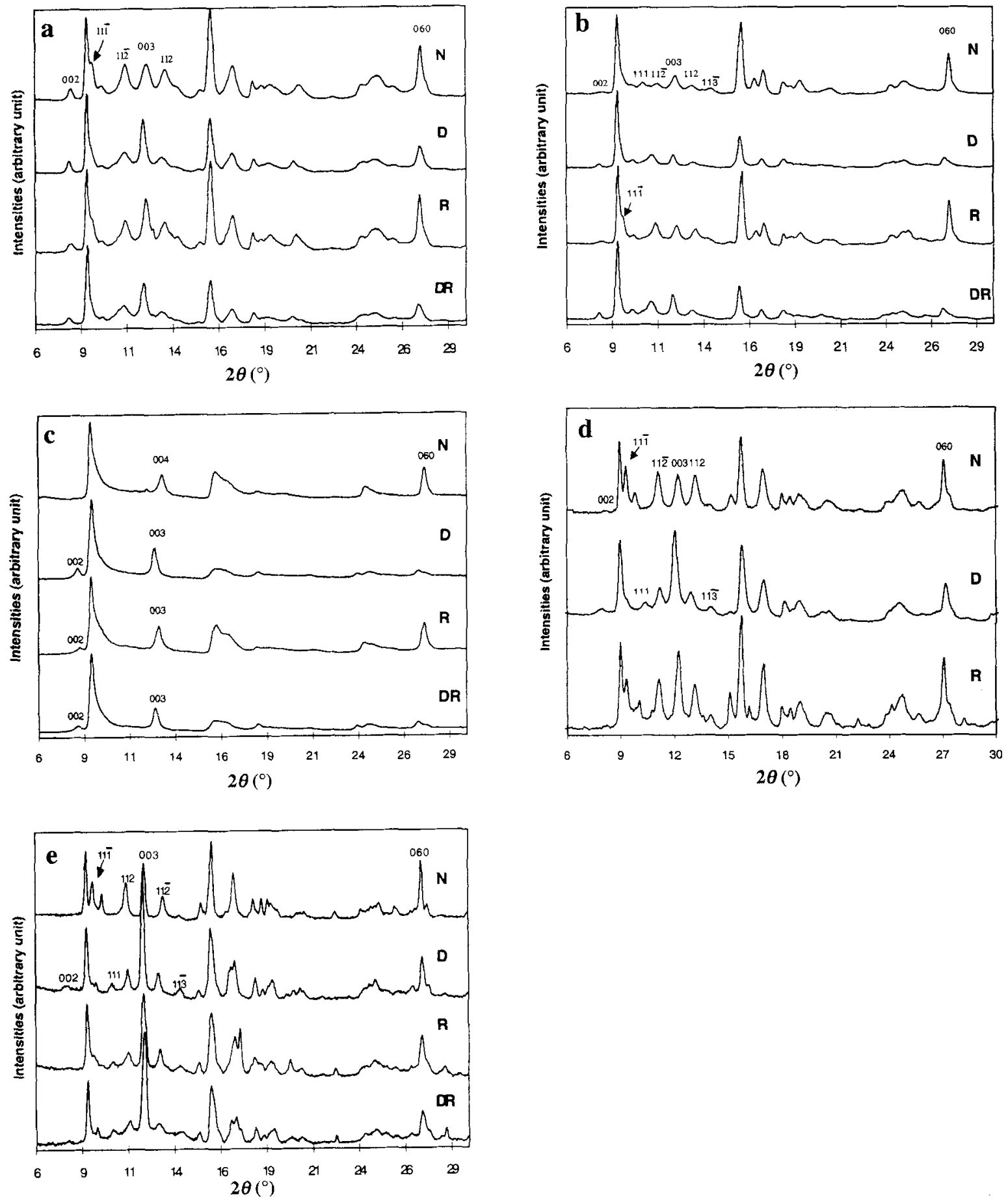

Figure 1. XRD patterns $(\lambda \mathrm{K} \alpha \mathrm{Mo}=0.70926 \AA$ ) of a) illite $60, \mathrm{~b}) \mathrm{cv} / \mathrm{tv}$ illite, c) Wyoming montmorillonite, d) glauconite 6869 , and e) celadonite 69 in natural (N), dehydroxylated (D), and rehydroxylated (R) states. XRD patterns of illite $60, c v /$ to illite, Wyoming montmorillonite, and celadonite 69 are also presented in de-rehydroxylated (DR) state.

(1993) and Drits et al. (1993) showed that the XRD patterns of dioctahedral $t v 3 T$ and $c v 1 M$ mica polytypes are very similar. Because, for the studied sample, $d(060)=1.501 \AA$, and the minimum periodicity along the $c^{*}$ axis is $9.966 \AA$, the hexagonal unit-cell parameters of the $3 T$ polytype should be $a=b / \sqrt{3}=$ $6 d(060) / \sqrt{3}=5.200 \AA, c=3 d(001)=29.899 \AA$, and $\gamma=120^{\circ}$. After indexing and determination of the $d$ 
Table 2. Unit-cell parameters and $c \cos \beta / a$ values of samples under study.

\begin{tabular}{|c|c|c|c|c|c|c|c|}
\hline Sample & State & $a(\AA)$ & $b(\AA)$ & $c(\AA)$ & $\left.\beta()^{\circ}\right)$ & $c \cos \beta / a$ & $d(001)(\AA)$ \\
\hline \multirow[t]{4}{*}{ Illite (sample 60) } & $\mathrm{N}$ & 5.238 & 9.018 & 10.14 & 101.48 & -0.385 & 9.933 \\
\hline & $\mathrm{D}$ & 5.265 & 9.024 & 10.24 & 100.98 & -0.374 & 10.050 \\
\hline & $\mathbf{R}$ & 5.252 & 9.042 & 10.16 & 101.46 & -0.387 & 9.956 \\
\hline & DR & 5.291 & 9.048 & 10.26 & 101.22 & -0.382 & 10.065 \\
\hline \multirow[t]{4}{*}{$c v / t v$ illite } & $\mathrm{N}$ & 5.214 & 9.006 & 10.12 & 99.97 & -0.337 & 9.966 \\
\hline & $\mathrm{D}$ & 5.299 & 9.108 & 10.34 & 102.11 & -0.413 & 10.110 \\
\hline & $\mathbf{R}$ & 5.265 & 9.018 & 10.17 & 101.52 & -0.390 & 9.966 \\
\hline & DR & 5.352 & 9.120 & 10.33 & 102.31 & -0.418 & 10.090 \\
\hline \multirow[t]{4}{*}{ Wyoming montmorillonite } & $\mathrm{N}$ & 5.193 & 8.994 & - & — & - & 12.560 \\
\hline & D & 5.241 & 9.078 & - & - & - & 9.708 \\
\hline & $\mathbf{R}$ & 5.196 & 9.000 & - & - & - & 9.558 \\
\hline & DR & 5.252 & 9.096 & - & - & - & 9.681 \\
\hline \multirow[t]{3}{*}{ Glauconite (sample 6869) } & $\mathrm{N}$ & 5.270 & 9.090 & 10.19 & 101.28 & -0.378 & 9.993 \\
\hline & D & 5.242 & 9.054 & 10.23 & 99.25 & -0.314 & 10.098 \\
\hline & $\mathrm{R}$ & 5.271 & 9.096 & 10.17 & 100.69 & -0.358 & 9.996 \\
\hline \multirow[t]{4}{*}{ Celadonite (sample 69) } & $\mathbf{N}$ & 5.220 & 9.060 & 10.22 & 100.92 & -0.371 & 10.062 \\
\hline & $\mathrm{D}$ & 5.233 & 9.030 & 10.21 & 98.78 & -0.299 & 10.089 \\
\hline & $\mathrm{R}$ & 5.235 & 9.060 & 10.26 & 99.24 & -0.315 & 10.128 \\
\hline & $\mathrm{DR}$ & 5.240 & 9.036 & 10.17 & 98.55 & -0.290 & 10.062 \\
\hline Average error & & $\pm 0.005 \AA$ & $\pm 0.006 \AA$ & $\pm 0.02 \AA$ & \pm 0.05 & & \\
\hline
\end{tabular}

values of the $3 T$ unit cell, the differences between the calculated spacings, $d_{\text {calc }}$, and experimental values, $d_{\exp }$, of the $101,102,104$, and 105 reflections vary from 0.004 to $0.009 \AA$. These differences are higher than the error of the measurement of the $d$ values. Hence, the $3 T$-polytype designation must be discarded. Indexing of the experimental XRD pattern based on a onelayer monoclinic unit cell, with $a=5.214 \AA, b=$ $9.006 \AA, c=10.12 \AA$, and $\beta=99.97^{\circ}$, provides the best agreement between the experimental and calculated $d(02 l, 11 l)$; the difference between $d_{\text {calc }}$ and $d_{\text {exp }}$ does not exceed $0.002 \AA$. Note that the $b$ parameter of the unit cell is not equal to $a \sqrt{3}$, as it must for the $3 T$ unit cell. One of the main differences between $t v$ $3 T$ and $c v 1 M$ polytypes is the $c \cos \beta / a$ value which is -0.333 for $t v 3 T$ (transformed into a one layer monoclinic unit-cell) and -0.300 for aluminous $c v 1 M$ polytypes (Drits et al., 1993). The $c \cos \beta / a$ value calculated for the monoclinic unit cell $(-0.337)$ of the studied sample is close to that of the $3 T$ polytype which has been discounted. The most reliable interpretation of the diffraction features is that the sample is composed of randomly interstratified $t v$ and $c v 2: 1$ layers with relative proportions near 0.4 and 0.6 as determined by the method proposed by Drits and McCarty (1996) using the experimental $d(11 l)$ values. Such an interpretation is confirmed below by DTG.

The positions and intensities of the $11 l$ and $02 l$ reflections in the XRD pattern of the $\mathrm{D}$ specimen are typical of dehydroxylated $t v 1 M$ illites (Figure 1b) with a $c \cos \beta / a$ value $(-0.413$, Table 2$)$ which significantly differs from $c \cos \beta / a=-0.337$ as determined for the $N$ specimen. The modification of the XRD pattern of the $\mathrm{D}$ specimen in comparison to that of the $\mathrm{N}$ pattern confirms a predominance of $c v 2: 1$ layers in the $\mathrm{N}$ structure. The XRD patterns of $\mathrm{N}$ and D $t v$-illites and muscovites are quite similar because the dehydroxylation of $t v 2: 1$ aluminous layers is not accompanied by an octahedral-cation migration (Guggenheim et al., 1987, 1990; Drits et al., 1995). In contrast, the XRD patterns of $\mathrm{N}$ and $\mathrm{D} c v$ illite should be substantially different owing to the migration of the $\mathrm{Al}$ cations from former trans-octahedra into empty cisprisms (Drits et al., 1995). An illite sample consisting of $c v$ and $t v$ layers is then expected to show the $t v$ characteristics in the D state, as is the case for this sample.

The XRD pattern of the $\mathrm{R}$ specimen is typical of a tv $1 M$ illite (Figure 1b; Table 2). As expected, the dehydroxylation of the rehydroxylate reproduces the main diffraction features of the D specimen (Figure 1b). This conclusion agrees with the thermal effects (Figure 2b). The DTG curve of the $\mathrm{N}$ sample contains two maxima: the weaker at $550^{\circ} \mathrm{C}$ and the stronger at $700^{\circ} \mathrm{C}$. These maxima respectively correspond to the dehydroxylation of $t v$ and $c v$ 2:1 layers (Drits et al., 1995, 1998). The DTG curve of the rehydroxylate contains only one maximum at $550^{\circ} \mathrm{C}$, which confirms the existence of only one type of layer in the rehydroxylated sample. This result indicates also the trans-

Figure 2. TG and DTG curves of a) illite 60, b) $c v / t v$ illite, c) Wyoming montmorillonite, d) glauconite 6869 , and e) celadonite 69 in natural (thin line) and rehydroxylated (thick line) states. 


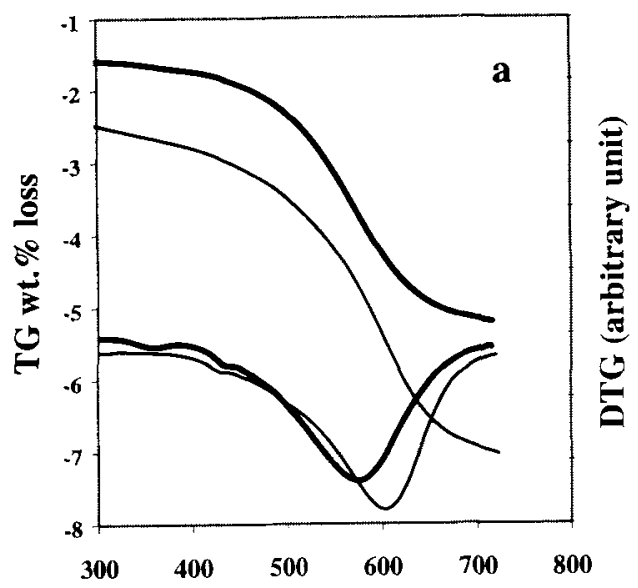

Temperature $\left({ }^{\circ} \mathrm{C}\right)$
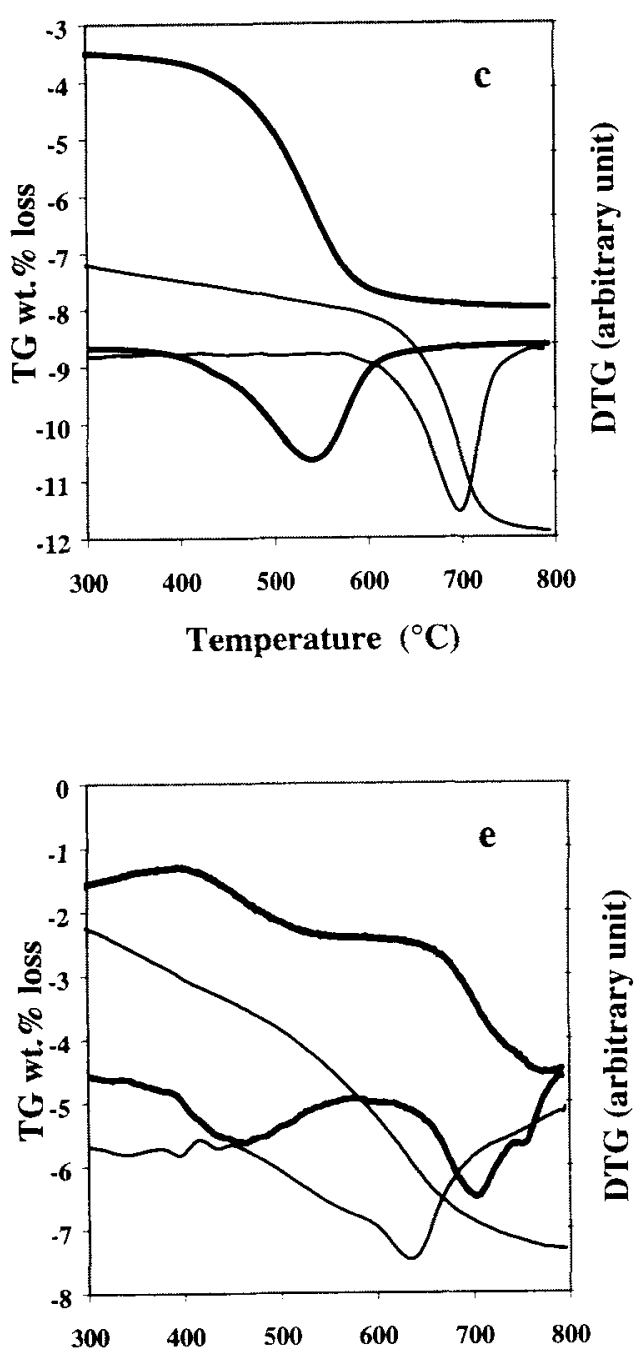

Temperature $\left({ }^{\circ} \mathrm{C}\right)$

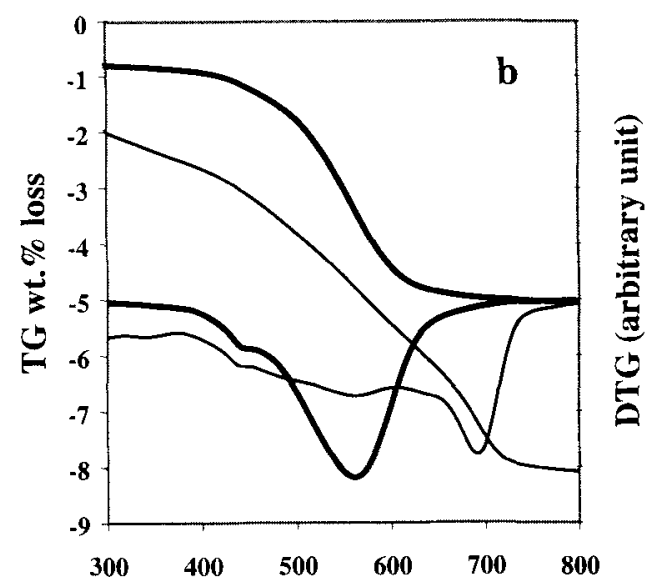

Temperature $\left({ }^{\circ} \mathrm{C}\right)$

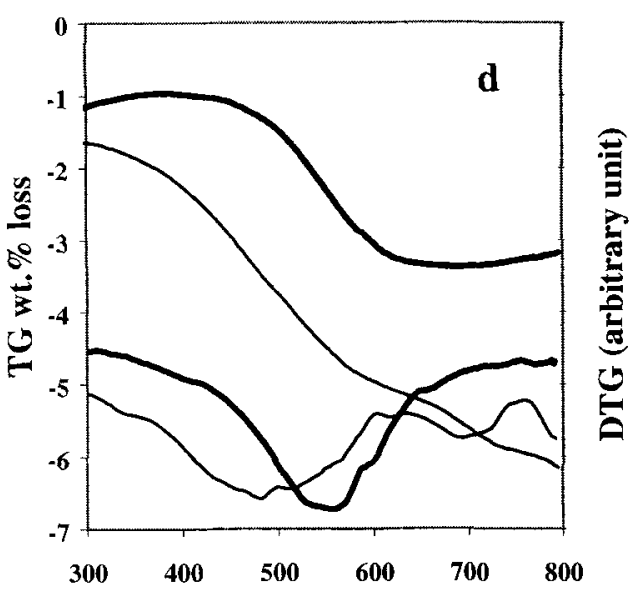

Temperature $\left({ }^{\circ} \mathrm{C}\right)$ 

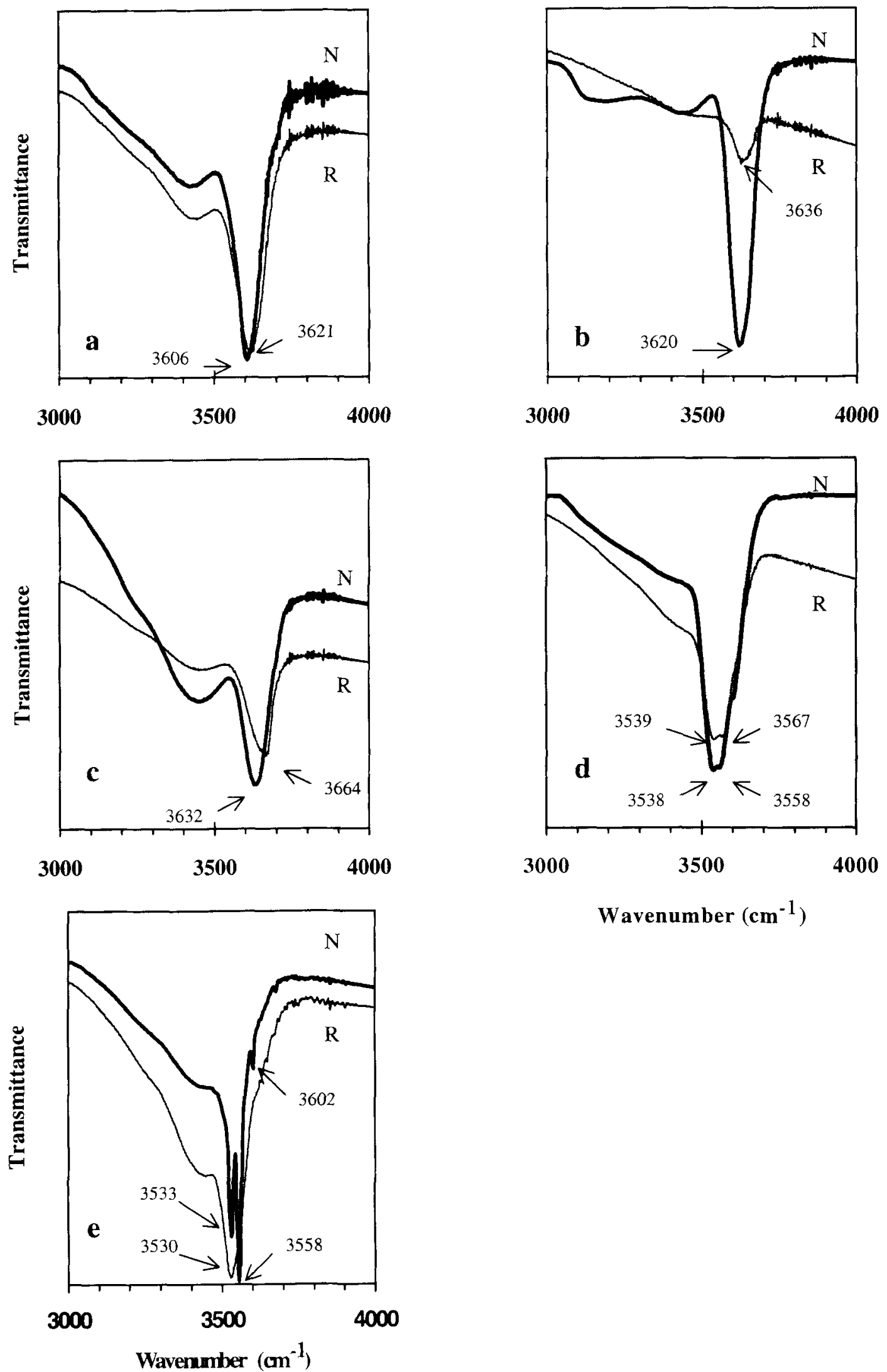
formation of $c v$ into $t v$ layers during dehydroxylation. The comparison of the IR spectra of the original and rehydroxylated specimens shows that rehydroxylation is accompanied by a significant decrease of the $\mathrm{OH}$ band and a displacement of its center from 3620 to $3636 \mathrm{~cm}^{-1}$ (Figure $3 \mathrm{~b}$ ).

\section{Wyoming montmorillonite}

The turbostratic stacking of the sample makes it impossible to determine the octahedral cation distribution over the trans- and cis-octahedra using XRD. However, it is noted that the XRD patterns of the $\mathrm{N}$ and $\mathrm{R}$ specimens are quite similar (Figure lc), except for $00 l$ reflections. The $\mathrm{N}$ specimen of Figure $1 \mathrm{c}$ is in its nat ural state $[d(001)=12.56 \AA]$ and the $\mathrm{R}$ sample is in a dried state $[d(001)=9.55 \AA$, Table 2]. The structure of the 2:1 layers of the $N$ and $R$ specimens can be deduced from the DTG curves (Figure 2c). The DTG curve of the $\mathrm{N}$ sample contains one strong maximum at $700^{\circ} \mathrm{C}$. This maximum corresponds to the dehydroxylation of $c v$ layers (Drits et al., 1995). In contrast, the dehydroxylation of the $\mathrm{R}$ specimen occurs at a lower temperature $\left(540^{\circ} \mathrm{C}\right)$ which corresponds to the dehydroxylation of $t v$ layers. Thus, the thermal effects show that the dehydroxylation-rehydroxylation process of the Wyoming montmorillonite induces the transformation of $c v$ to $t v$ layers. As for the $t v$ illite and the $c v / t v$ illite described previously, the main intensity band in the IR spectrum of the rehydroxylate shifts to a higher value compared to that of the original specimen from 3632 to $3664 \mathrm{~cm}^{-1}$.

\section{Glauconite (sample 6869)}

The main diffraction features of the sample in its $\mathrm{N}$, D, and R states (Figure 1d) show that dehydroxylation is accompanied by a migration of octahedral cations from cis-into trans-sites. For the D specimen, the rather weak $111,11 \overline{2}, 112$, and $11 \overline{3}$ maxima typical for $c v$ $1 M$ dioctahedral micas replace the strong $11 \overline{1}, 11 \overline{2}$, and 112 reflections observed for the $\mathrm{N}$ specimen, and typical of tv $1 M$ dioctahedral micas (Figure 1d). A significant decrease in the relative displacement of adjacent layers from -0.378 for the $\mathrm{N}$ specimen to -0.314 for the $D$ sample confirms that cation migration occurs. Drits et al. (1997) showed that the $c$ cos $\beta / a$ value of dioctahedral $1 M$ micas depends on their chemical composition. The higher the content of octahedral $\mathrm{Fe}^{2+}$ and $\mathrm{Mg}$, the lower the $|c \cos \beta / a|$ value. For this reason, the $|c \cos \beta / a|$ value for the $\mathrm{N}$ specimen is lower than the values of $t v 1 M$ illites. According to the procedure described by Drits et al. (1984a), a transformation of $t v 1 M$ to $c v 1 M$ dioctahedral mica with the chemical composition of sample 6869 should change the $c \cos \beta / a$ values from -0.378 to -0.311 . The latter is close to the -0.314 value determined for the D specimen (Table 2). The XRD patterns of the $\mathrm{N}$ and $R$ specimens are quite similar with respect to the reflection-intensity distribution. This indicates that the rehydroxylation process is accompanied by a reverse cation migration. However, the $|c \cos \beta / a|$ value for the $R$ specimen $(-0.358)$ is significantly lower than that $(-0.378)$ for the $\mathrm{N}$ specimen. According to Drits and McCarty (1996), the R specimen should contain 25-30\% of $c v 2: 1$ layers based on this value. Thus, after rehydroxylation, most layers have trans-vacant octahedra. As a side effect, the dehydroxylation-rehydroxylation process slightly disturbs the structure, with the characteristic appearance of a slight increase in background at the $02 l$ and $11 l$ reflections.

Note that the IR spectra of the $\mathrm{N}$ and $\mathrm{R}$ specimens in the stretching vibration region are quite similar (Figure 3d), with two bands located near 3538 and $3558 \mathrm{~cm}^{-1}$ for the $\mathrm{N}$ specimen, and near 3539 and $3567 \mathrm{~cm}^{-1}$ for the $\mathrm{R}$ specimen. The DTG patterns of the $\mathrm{N}$ and $\mathrm{R}$ samples have a broad maximum at 480 and $560^{\circ} \mathrm{C}$, respectively. The small dehydroxylation peak at $700^{\circ} \mathrm{C}$ probably corresponds to a carbonate impurity.

\section{Celadonite (sample 69)}

The XRD patterns for the $\mathrm{N}$ and $\mathrm{D}$ specimens of the celadonite and glauconite samples are quite similar (Figure $1 \mathrm{~d}$ and 1e). This shows that the dehydroxylation of both minerals is accompanied by an octahedralcation migration from cis into former trans-sites. A significant decrease of $|c \cos \beta / a|$ from 0.371 for the $\mathrm{N}$ specimen of celadonite to 0.299 for the $\mathrm{D}$ specimen confirms this conclusion. The value of $|c \cos \beta / a|=$ 0.371 for the $\mathrm{N}$ specimen is related to a high content of $\mathrm{Mg}$ and $\mathrm{Fe}^{3+}$, as for the glauconite sample. The similarity of the XRD patterns for the D and R specimens (Figure 1e) shows that their 2:1 layers have a near identical cation distribution. Also, their $c \cos \beta / a$ values are similar $(-0.299 v s$. -0.315$)$. If the relative displacement of adjacent $c v$ layers in dioctahedral micas having a celadonite composition is -0.299 or -0.290 as found in the D and DR specimens, respectively (Table 2), then, according to Drits and McCarty (1996), the R specimen should contain 25-30\% of $t v$ 2:1 layers. Then, after rehydroxylation, there is no reverse cation migration from former trans- to empty cis-octahedra for most of the layers. In this respect, the structural transformation of the dehydroxylated celadonite and glauconite samples during the rehy-

Figure 3. IR spectra in the $\mathrm{OH}$-stretching region of a) illite $60, \mathrm{~b})(v / t v$ illite, c) Wyoming montmorillonite, d) glauconite 6869 , and e) celadonite 69 in natural $(\mathrm{N})$ and rehydroxylated $(\mathrm{R})$ states. 
droxylation process differs substantially. A small reverse cation migration occurs in celadonite whereas considerable reverse cation migration occurs in glauconite. The dehydroxylation of the $\mathrm{R}$ specimen of celadonite is not accompanied by significant cation migration $(c \cos \beta / a=-0.290$, Table 2$)$, and the former trans-sites remain occupied.

The DTG curves of the celadonite sample (Figure $2 e)$ agree with the transformations described above. The DTG curve of the original sample (Figure $2 \mathrm{e}$ ) can be described by two peaks near 550 and $650^{\circ} \mathrm{C}$, which cannot be assigned, respectively, to $t$ and $c v$ layers because XDR shows unambiguously that the sample contains only $t v$ layers. A water loss showing two peaks has been observed in pyrophyllite and muscovite by Guggenheim (1990), and in illite-smectites by Drits et al. (1998). Guggenheim (1990) explained this effect by the change of coordination of the Al nextnearest neighbors of the $\mathrm{OH}$ pairs during dehydroxylation. In celadonite, the existence, within the layers, of domains differing in the octahedral cation distribution (Drits et al., 1997), can also induce a heterogenous loss of water. The maximum water lost at $650^{\circ} \mathrm{C}$ is significantly higher than that observed for $t v$ Al-rich dioctahedral 2:1 layer silicates. Drits et al. (1998) showed that for the Al-rich $c v$ and $t v$ layers, the dehydroxylation temperatures $\left(T_{d}\right)$ are, respectively, below and above $600^{\circ} \mathrm{C}$. Two factors can be responsible for a higher value of $T_{d}$ for celadonites. First, according to crystal structure refinements (Zvyagin, 1967; Drits et al., 1984b), octahedral sheets of celadonite 2:1 layers are significantly thicker than sheets of illites. The thicker the octahedral sheet, the longer the $\mathrm{OH}$ $\mathrm{OH}$ shared edges. More thermal energy is then required for dehydroxylation. Second, a local compensation of the negative charge of the residual oxygen atoms in a mica dehydroxylate is more difficult to occur if these oxygen atoms are coordinated by divalent cations. Therefore, it is likely that the greater the amount of divalent octahedral cations in 2:1 layers, the greater the resistance of these layers to be transformed and the higher the thermal energy required for the layer dehydroxylation. The DTG curve of the R specimen has a maximum water loss at $700^{\circ} \mathrm{C}$ (Figure 2e). This increase of $T_{d}$ in comparison with that of the original sample confirms a presence of $c v$ 2:1 layers in the rehydroxylated structure. The maximum in water loss observed at $450^{\circ} \mathrm{C}$ in the DTG curve of the rehydroxylate corresponds to the dehydroxylation of $t v 2: 1$ layers.

Figure 3e shows that the well resolved IR spectrum of the original sample is replaced by a single wide $\mathrm{OH}$ band at $3530 \mathrm{~cm}^{-1}$. The "center of gravity" of the $\mathrm{OH}$ band in the $\mathbf{R}$ sample shifts to a lower frequency in comparison with that in the $\mathrm{N}$ specimen (Figure 3 ). This is the opposite behavior of the studied Al-rich samples.

\section{DISCUSSION}

The data obtained by TGA and IR spectroscopy confirm that the experimental rehydroxylation process produces hydroxylation of the samples. The results obtained here show that the structural features of dehydroxylated and rehydroxylated dioctahedral 2:1 layer silicates depend on their chemical composition as well as on the original distribution of octahedral cations over cis- and trans-sites. Dioctahedral 2:1 phyllosilicates in their initial state can be subdivided into three main groups: Al-rich $t v$, Al-rich $c v$, and $\mathrm{Fe}^{3+}, \mathrm{Mg}$-rich ( $\left.{ }^{\mathrm{VI}} \mathrm{Fe}^{3-},{ }^{\mathrm{V}} \mathrm{Mg}>{ }^{\mathrm{V}} \mathrm{Al}\right)$ $\mathcal{N} 2: 1$ minerals. Rehydroxylated dioctahedral 2:1 layer silicates are subdivided into two groups. The first group consists of rehydroxylated Alrich minerals, which are composed of $t v$ layers regardless of the distribution of the octahedral cations over cis- and trans-sites in the original structures. The second group is represented by the $\mathrm{Fe}^{3+}, \mathrm{Mg}$-rich minerals for which tv 2:1 layers are transformed into $c v$ ones during dehydroxylation, and preserve this structure partially after rehydroxylation. Table 3 summarizes the main structural transformations of the studied samples during dehydroxylation and rehydroxylation reactions. To trace the structural transformations of dioctahedral 2:1 layer silicates during the dehydroxylation-rehydroxylation reactions, it is useful to consider the causes of the structural transitions within each subgroup.

\section{Trans-vacant illites}

As mentioned above, the cation distribution in the octahedral sheet in the dehydroxylated state of these minerals is the same as that in the natural state. No cation migration occurs. These cations become fivecoordinated, the residual oxygen atoms $\mathrm{O}_{\mathrm{r}}$ being located at the same $z$ coordinate as octahedral cations and midway between them. We assume that a structural rearrangement takes place in reverse order during the rehydroxylation process: water molecules migrate into the sample and react with the residual oxygen atom according to $\mathrm{H}_{2} \mathrm{O}+\mathrm{O}_{\mathrm{r}} \rightarrow 2(\mathrm{OH})$. This reaction reconstructs the octahedral coordination of the $\mathrm{Al}$ cations bonded to the newly formed OH groups. Thus, the original structural arrangement of the 2:1 layers is recovered. However, as shown in Table 2, the transition from the $N$ to $R$ state of sample 60 leads to a noticeable increase of the $a$ and $b$ unit-cell parameters. This effect is unexpected. It is obvious that dehydroxylation alone cannot change the valency of the octahedral cations present in sample 60 (mainly $\mathrm{Al}$ and $\mathrm{Mg}$, Table 1). Cis-octahedral cation occupancy and composition should also be the same in the $\mathrm{N}$ and $\mathrm{R}$ specimens.

\section{Cis-vacant and cv/tv illite and smectites}

The structural transitions of the octahedral sheet of an original Al-rich $c v 2: 1$ layer to its $\mathrm{D}$ and $\mathbf{R}$ states 
Table 3. The main structural transformations of the studied samples after dehydroxylation and rehydroxylation reactions.

\begin{tabular}{|c|c|c|c|}
\hline \multirow[b]{2}{*}{ Sample } & \multicolumn{3}{|c|}{ Status } \\
\hline & $N$ & D & $\mathrm{R}$ \\
\hline Illite (sample 60) & to layers & $\begin{array}{l}\text { no cation migration, five-fold coordina- } \\
\text { tion of } \mathrm{Al} \text { and } \mathrm{Mg} \text { cations, location } \\
\text { of a residual oxygen atom, } \mathrm{O}_{\mathrm{r}}, \mathrm{mid}- \\
\text { way between two closest } \mathrm{Al}, \mathrm{Mg} \\
\text { cations. }\end{array}$ & $\begin{array}{l}\text { no cation migration, reconstruction of } \\
t v \text { layers due to the reaction } \\
\mathrm{O}_{\mathrm{r}}+\mathrm{H}_{2} \mathrm{O} \rightarrow 2(\mathrm{OH}) \text {. }\end{array}$ \\
\hline$c v / t v$ illite & $c v / t v$ & $\begin{array}{l}\text { migration of the cations into vacant } \\
\text { cis-sites in } c v \text { layers and formation } \\
\text { of a structure similar to that of de- } \\
\text { hydroxylated to illites. }\end{array}$ & $\begin{array}{l}\text { no cation migration, all layers are } t v \text {, } \\
\text { as in the previous case. }\end{array}$ \\
\hline Wyoming montmorillonite & $c v$ & $\begin{array}{l}\text { migration of octahedral cations into } \\
\text { vacant cis-sites and formation of a } \\
\text { structure similar to that of dehydrox- } \\
\text { ylated tv illites. }\end{array}$ & no cation migration, all layers are $t v$. \\
\hline Glauconite (sample 6869) & $t v$ & $\begin{array}{l}\text { migration of octahedral cations into } \\
\text { vacant former trans-sites, location of } \\
\text { a residual oxygen atom, } \mathrm{O}_{\mathrm{r}} \text {, in one } \\
\text { of two possible positions of } \mathrm{OH} \\
\text { groups. }\end{array}$ & $\begin{array}{l}\text { partial reverse cation migration from } \\
\text { former trans-sites into empty cis- } \\
\text { sites and formation of } 70-75 \% \mathrm{t} \\
\text { layers. No cation migration in the } \\
\text { remaining } 25-30 \% \text { of layers which } \\
\text { are } \mathrm{cv} \text {. }\end{array}$ \\
\hline Celadonite (sample 69) & tv & $\begin{array}{l}\text { migration of octahedral cations into } \\
\text { vacant former trans-sites, location of } \\
\text { a residual oxygen atom, } \mathrm{O}_{r} \text {, in one } \\
\text { of two possible positions of } \mathrm{OH} \\
\text { groups. }\end{array}$ & $\begin{array}{l}\text { there is no cation migration in most } \\
\text { layers, but }-20-30 \% \text { of them have } \\
\text { been transformed into } t v \text { layers ow- } \\
\text { ing to the cation migration. }\end{array}$ \\
\hline
\end{tabular}

are shown schematically in Figure 4. As seen in Figure $4 \mathrm{a}$, each of the two adjacent $\mathrm{OH}$ groups form nonshared edges which are considerably longer than shared $\mathrm{OH}-\mathrm{OH}$ edges in $t v$ layers. For the latter, the $\mathrm{OH}$ groups screen the electrostatic repulsion between octahedral cations. For $t v$ layers, the dehydroxylation of $c v$ layers is accompanied by the replacement of two adjacent $\mathrm{OH}$ groups by a residual oxygen atom. The Al cations that originally occupied cis- and trans-sites become five- and six-coordinated, respectively (Figure 4b). The structure of the dehydroxylated 2:1 layers is unstable because the bond lengths between the sixcoordinated $\mathrm{Al}$ cations and the oxygen atoms are unrealistically long relative to unheated structures. Drits et al. (1995) showed that no shift of octahedral cations or anions can provide an appropriate charge saturation of the oxygen atoms of the octahedral polyhedron. Structural stabilization is obtained by the migration of the $\mathrm{Al}$ cations from the former trans-sites to the empty five-coordinated prisms. The resulting structure (Figure $4 c$ ) is identical to that of the $t v$ dehydroxylates where the Al cations provide homogeneous localcharge compensation. During rehydroxylation these heat-treated layers remain as $t v$ layers (Figure 4d).

The XRD data, as well as the DTG curves, obtained for $c v / t v$ illite and Wyoming smectite are consistent with this model. The difference in the $\mathrm{OH}-\mathrm{OH}$ lengths in the original $c v$ layer (Figure $4 \mathrm{a}$ ) and rehydroxylated tw layer (Figure 4d) explains the significant decrease in dehydroxylation temperatures for the $\mathbf{R}$ specimens of $c v / t v$ illite and Wyoming montmorillonite (Figure
$2 \mathrm{~b}$ and 2c) as proposed by Drits et al. (1995). An explanation based on an energy rise required for octahedral-cation migration is discarded. Dehydroxylation induces cation migration in layers of glauconite and celadonite. Nevertheless, Figure $2 d$ and $2 \mathrm{e}$ shows that dehydroxylation temperatures are lower for the $\mathrm{N}$ samples.

The transition from $\mathrm{N}$ to $\mathrm{D}$ as well as from the $\mathrm{R}$ to DR states of $c v / t v$ illite leads to a significant increase of $a, b$, and $c$ unit-cell parameters (Table 2). Drits et al. (1995) noted that the main reason for the increase of the $b$ parameters for dehydroxylated $\mathrm{Al}-$ rich 2:1 layers is a tendency for octahedral cations to move away from each other along the $b$ axis to increase the $\mathrm{Al}-\mathrm{O}_{\mathrm{r}}$ distance to an appropriate equilibrium value. The observed decrease of these parameters in the rehydroxylates compared to those in the dehydroxylated specimens (Table 2) is a direct consequence of the replacement of the residual oxygen atom by two $\mathrm{OH}$ groups, which reconstructs an octahedral coordination for cations and provides cation-anion bond lengths appropriate for this coordination, and with lower $a$ and $b$ parameters. Rehydroxylation reconstructs the original $9.966-\AA$ periodicity along the $c^{*}$ axis (Table 2). The significant increase of the $d(001)$ value for the $D$ and DR specimens may be the result of trapping $\mathrm{H}_{2} \mathrm{O}$ molecules within the interlayers which leave the structure during dehydroxylation. The transformation of $c v$ layers to $t v$ layers in Wyoming montmorillonite has a negligible influence on the unitcell parameters (Table 2). A similar negligible effect 
may also be the case for all dioctahedral Al-rich smectites; $c v$ and $t v 2: 1$ layers of identical octahedral cation composition should have identical or nearly identical unit-cell lateral dimensions.

\section{$F e^{3+}$-rich dioctahedral to $2: 1$ layer silicates}

The structural transformations in celadonites and glauconites from the original to the dehydrated state and then to the rehydroxylated state are shown schematically in Figure 5. As previously, it might be assumed that during dehydroxylation, adjacent $\mathrm{OH}$ groups are replaced by a residual $\mathrm{O}_{\mathrm{r}}$ oxygen atom. The $\mathrm{O}_{\mathrm{r}}$ atom locates midway between and at the same $z^{-}$ coordinate level as the octahedral cations, and occupied octahedra are transformed into five-coordinated prisms (Figure $5 b$ ). In such cases, the octahedral cation- $\mathrm{O}_{\mathrm{r}}$ distance will become $b / 6$, i.e., $1.51-1.52 \AA$, and this distance is too short for cations with pentagonal coordination. Therefore, the octahedral cations must move away from each other, as observed in dehydroxylated muscovite where the $\mathrm{Al}-\mathrm{O}_{\mathrm{r}}$ distance is $1.69 \AA$ (Udagawa et al., 1974). According to Drits et al. (1995), such a rearrangement of the $\mathrm{Al}$ and $\mathrm{O}_{\mathrm{r}}$ atoms is the main reason for the larger $a$ and $b$ parameters compared to the original values. The cations $\mathrm{Fe}^{2+}, \mathrm{Mg}$, and $\mathrm{Fe}^{3+}$ are relatively large in comparison with $\mathrm{Al}^{3+}$. Thus the replacement of $\mathrm{Al}$ by $\mathrm{Fe}$ and $\mathrm{Mg}$ should increase the cation- $\mathrm{O}_{\mathrm{r}}$ distance and increase the $b$ parameter in a way that is not compatible with the limited lateral expansion of the tetrahedral sheets. Tsipursky et al. (1985) argued that this factor is responsible for the cation migration from cis- to trans-sites. The main reason for this assumption was that cation migration is absent in glauconites where the content of ${ }^{\mathrm{VI}}(\mathrm{Fe}+$ $\mathrm{Mg}$ ) is lower or equal to the ${ }^{\mathrm{V}} \mathrm{Al}$ content. However, Muller et al. (2000) showed by simulation of XRD patterns, that for Fe-rich dioctahedral layer silicates $\left[{ }^{{ }^{\mathrm{l}}}(\mathrm{Fe}+\mathrm{Mg}) \geq{ }^{\mathrm{VI}} \mathrm{Al}\right], \mathrm{O}_{\mathrm{r}}$ atoms in the $\mathrm{D}$ structure are located in former $\mathrm{OH}$ positions, eliminating the problem of the short $\mathrm{Fe}, \mathrm{Mg}-\mathrm{O}_{\mathrm{r}}$ distances. Figure 5c shows a model where the $\mathrm{O}_{\mathrm{r}}$ atoms occupy one of the two former hydroxyl sites distributed along the [100] direction with a period equal to the $a$ parameter; $\mathrm{Fe}, \mathrm{Mg}$ cations have five-coordination and are located in the former cis-sites. Figure 5d shows an arrangement for the dehydroxylated octahedral sheet, assuming an additional cation migration from cis- to trans-sites, in comparison with Figure 5c. These two structural models (Figure $5 c$ and $5 \mathrm{~d}$ ), having different cation distributions, are characterized by different stability fields, which can be estimated by using the Pauling electrostatic valency principle. In both models the residual anions are strongly undersaturated with respect to positive charge because they receive this charge only from two five-coordinated cations. The degree of undersaturation may be decreased by a shortening of the cation-residual anion bonds because the shorter the bond
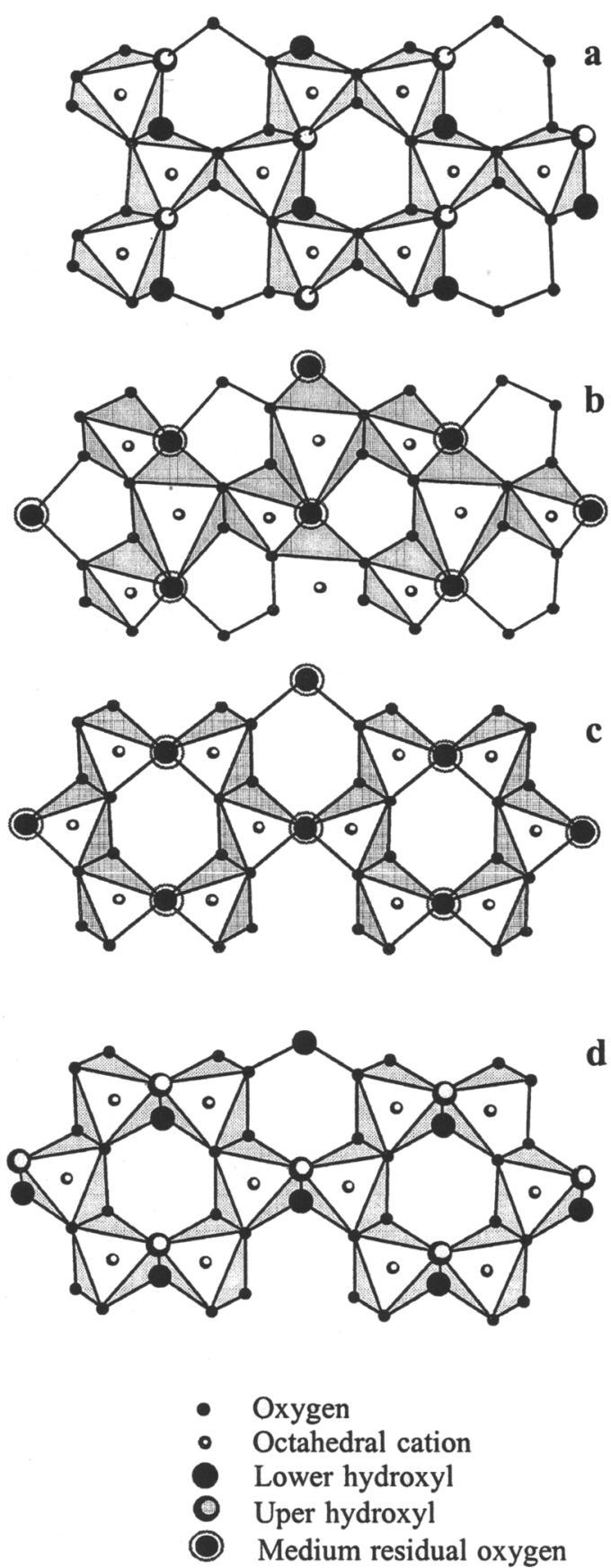

Figure 4. Schematical representation of octahedral sheet during the dehydroxylation-rehydroxylation reaction of $\mathrm{Al}$ rich $c v$ 2:1 layers silicates. Natural state (a), dehydroxylation (b), cations migration (c), and rehydroxylated to state (d).

length, the greater the bond strength, i.e., the higher the saturation of the anion by positive charge. Because cation repulsion should be screened by anions, note that in the trans-vacant dehydroxylate model (Figure $5 c)$ the smaller cation to $O_{r}$ distances must greatly increase cation-cation repulsion. These repulsions occur 

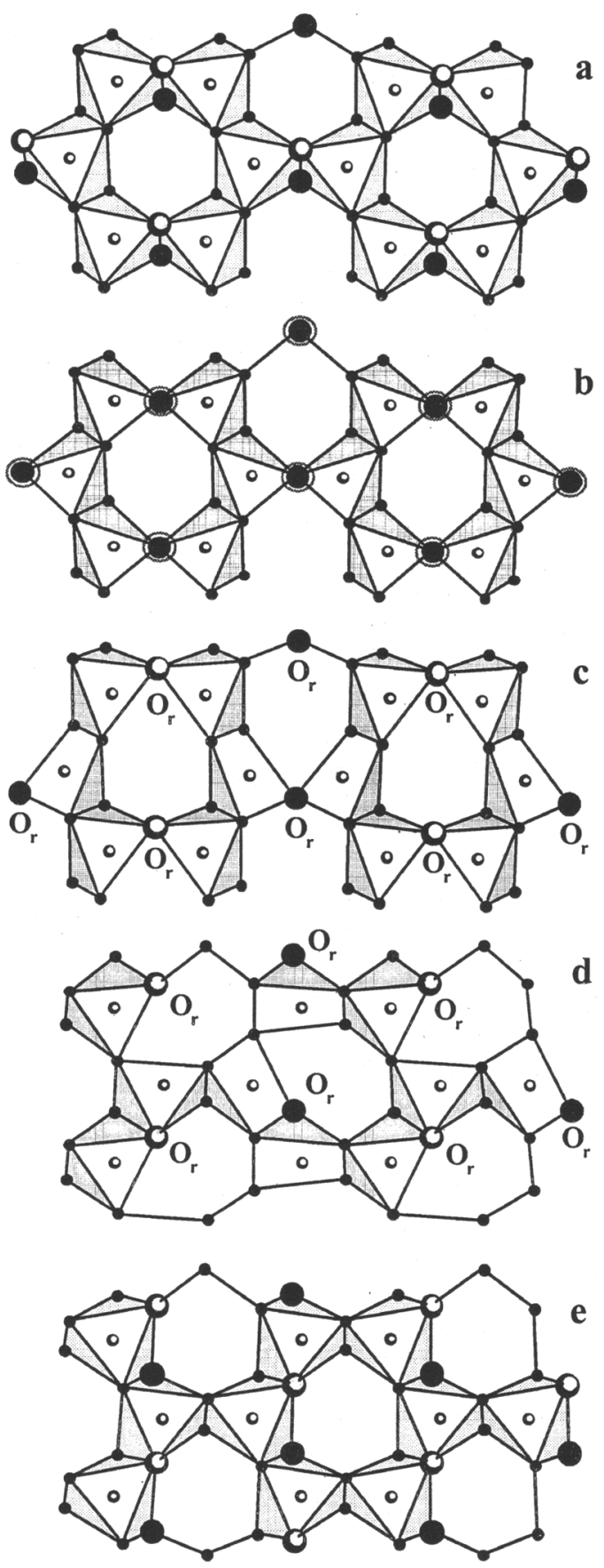

- Oxygen

- Octahedral cation

- Lower hydroxyl or residual oxygen

- Uper hydroxyl or residual oxygen

Medium residual oxygen

Figure 5. Schematical representation of octahedral sheet during the dehydroxylation-rehydroxylation reaction of $\mathrm{Fe}$ rich $t v$ 2:1 layers silicates. Natural state (a), dehydroxylation (c), cations migration (d), and rehydroxylated $c v$ state (e). The because only one $O_{r}$ anion provides the required screening of repulsions caused by each of the two nearest cations along the $b$ axis (Figure 5c). In addition, the $\mathrm{O}_{\mathrm{r}}$ anion is not at the same $z$ level as the cations. In contrast, in the dehydroxylate cis-vacant model (Figure 5d), the repulsion of cations bonded to the $\mathrm{O}_{\mathrm{r}}$ anion is screened by shortened anion edges, which occurs also in non-heated dioctahedral 2:1 layers. Thus, the octahedral-cation migration and location of the residual oxygen atoms in the former $\mathrm{OH}$ sites stabilize the dehydroxylate structure of celadonites and glauconites. The migration of octahedral cations from cis- to trans-sites was observed in these dehydroxylated minerals by Tsipursky et al. (1985). The former $t v$ layers are transformed into layers with vacant fivefold prisms formed from the former cis-octahedra. The observed decrease of $b$ for dehydroxylated samples 69 and 6869 is in accordance with cation migration (Table 2 ). The values of $c \cos \beta / a$ for the original and dehydroxylate samples also agrees with the location of $\mathrm{Fe}, \mathrm{Mg}$ cations in the sites as described above.

Figure 5e illustrates the rehydroxylation process with the replacement of each $\mathrm{O}_{\mathrm{r}}$ anion by two $\mathrm{OH}$ groups in $c v 2: 1$ layers. The positions and intensity of $h k l$ reflections in the XRD patterns of rehydroxylated celadonite (Figure 1e) as well as the unit-cell parameters and the mutual disposition of adjacent layers (Tables 2) are consistent with the model described. Note that after rehydroxylation a portion of the dehydroxylated layers $(25-30 \%)$ in the celadonite sample returns to a $t v$ sheet. A more complex transformation takes place for the glauconite sample. For dehydroxylated glauconite, rehydroxylation of the 2:1 layers is accompanied by reverse cation migration from the former trans-sites into empty prisms and the replacement of $\mathrm{O}_{\mathrm{r}}$ anions by pairs of $\mathrm{OH}$ groups. As a result, the glauconite rehydroxylate consists of the interstratification of 70-75\% tv and 25-30\% $\mathrm{cv}$ layers. This effect may be related to partial heterogeneity in the cation composition of individual 2:1 layers in the original samples. During rehydroxylation, the layers with a higher $\mathrm{Al}$ content are transformed into to layers whereas layers with a lower $\mathrm{Al}$ content preserve the cation distribution of the dehydroxylate. Probably, the reverse migration of octahedral $\mathrm{Al}$ cations to vacant $c i s$-sites of $\mathrm{R}$ layers provides a more stable configuration.

\section{ACKNOWLEDGMENTS}

The authors are very grateful to J. Cuadros and L. HellerKallai for their valuable comments and English corrections. The authors thank also M. Pioffet for his participation during his D.E.A. training and D. Horton for providing the $c v / t v$

$\leftarrow$

situation for (b) corresponds to the model of Al-rich $t v 2: 1$ layer silicates where the residual oxygen atoms move to the same $z$ coordinate as the octahedral cations. 
sample. V. Drits thanks the Russian Fundamental Science Foundation and Orléans University for financial support.

\section{REFERENCES}

Bailey, S.W. (1984) Crystal chemistry of the true micas. In Micas, Reviews in Mineralogy, Volume 13, S.W. Bailey, ed., Mineralogical Society of America, Washington, D.C., 13-60.

Brindley, G.W. (1976) Thermal transformations of clays and layer silicates. In Proceedings of International Clay Conference, 1975, J. Fripiat, ed., Applied Publishing Ltd., Wilmette, Illinois, USA, 119-129.

Cuadros J. and Altaner S.P. (1998) Composition and structural features of the octahedral sheet in mixed-layer illite/smectite from bentonites. European Journal of Mineralogy, 10, $111-124$.

Drits, V.A. and McCarty, D.K. (1996) The nature of diffraction effects from illite-smectite consisting of interstratified trans-vacant and cis-vacant 2:1 layers: A semiquantitative technique for determination of layer-type content. American Mineralogist, 81, 852-863.

Drits, V.A., Plançon, A., Sakharov, B.A., Besson, G., Tsipursky, S.I., and Tchoubar, C. (1984a) Diffraction effects calculated for structural models of $\mathrm{K}$-saturated montmorillonite containing different types of defects. Clay Minerals, 19, 541-562.

Drits, V.A., Tsipursky, S.I., and Plançon, A. (1984b) Application of the method for the calculation of intensity distribution to electron diffraction structural analysis. Izvestiya Akademii Nauk S.S.S.R., Seriya Physica, 2, 1708-1713. (in Russian).

Drits, V.A., Weber, F., Salyn, A.L., and Tsipursky, S.I. (1993) $\mathrm{X}$-ray identification of one-layer illite varieties: Application to the study of illite around uranium deposits of Canada. Clays and Clay Minerals, 41, 389-398.

Drits, V.A., Besson, G., and Muller, F. (1995) An improved model for structural transformations of heat-treated aluminous dioctahedra 2:1 layer silicates. Clays and Clay Minerals, 43, 718-731.

Drits, V.A., Salyn, A.L., and Sucha, V. (1996) Structural transformation of illite-smectite from Dolva Ves hydrothermal deposite: Dynamics and mechanisms. Clays and Clay Minerals, 44, 181-196.

Drits, V.A., Dainyak, L.G., Muller, F., Besson, G., and Manceau, A. (1997) Isomorphous cation distribution in celadonites, glauconites and Fe-illites determined by infrared, Mössbauer and EXAFS spectroscopies. Clay Minerals, 32, 153-179.

Drits, V.A., Lindgreen, H., Salyn, A.L., Ylagan, R., and McCarty, D.K. (1998) Semiquantitative determination of trans-vacant and cis-vacant 2:1 layers in illites and illitesmectites by thermal anlysis and X-ray diffraction. American Mineralogist, 83, 1188-1198.

Emmerich, K., Thule Madsen, F, and Kahr, G. (1999) Dehydroxylation behavior of heat-treated and steam-treated homoionic cis-vacant montmorillonites. Clays and Clay Minerals, 47, 591-604.

Grim, R.E. (1968) Clay Mineralogy: International Series in the Earth and Planetary Sciences. McGraw-Hill Book Company, New York, 596 pp.

Grim, R.E., Bradley, W.F, and Brown, G. (1951) X-ray Identification and Crystal Structures of Clay Minerals, G.W. Brindley, ed., Mineralogical Society, London, 138-172.

Guggenheim, S. (1990) The dynamics of thermal decomposition in aluminous dioctahedral 2: 1 layer silicates: A crystal chemical model. In Proceedings of 9th International Clay Conference, Volume 2, V.C. Farmer and Y. Tardy, eds., Strasbourg, France, 99-107.
Guggenheim, S. and Koster van Groos, A.F. (1992) Highpressure differential thermal analysis (HP-DTA). II. Dehydroxylation reactions at elevated pressures in phyllosilicates. Joumal of Thermal Analysis, 38, 2529-2548.

Guggenheim, S., Chang, H.Y, and Koster van Groos, A.F. (1987) Muscovite dehydroxylation: High-temperature studies. American Mineralogist, 72, 537-550.

Heller-Kallai, L. and Rozenson, I. (1980) Dehydroxylation of dioctahedral phyllosilicates. Clays and Clay Minerals, 28, 355-368.

Heller-Kallai, L., Farmer, V.C., Mackenzie, R.C., Mitchell, B.D., and Taylor, H.F.W. (1962) The dehydroxylation and rehydroxylation of triphormic dioctahedral clay minerals. Clay Minerals Bulletin, 5, 56-72.

Horton, D. (1983) Argilitic alteration. Association with the amethyst vein system. Ph.D. thesis, University of Illinois, Urbana-Champaign, Illinois, USA.

Ivanovskaya, T.A., Tsipursky, S.I., and Yakovleva, O.V. (1989) Mineralogy of globular glauconites from Vendian and Rephean of the Ural and Siberia. Litologiya Poleznye Iskopaemye, 3, 83-89. (in Russian).

Koster van Groos, A.F and Guggenheim, S. (1987) Highpressure differential thermal analysis (HP-DTA) of the dehydroxylation of Na-rich montmorillonite and K-exchanged montmorillonite. American Mineralogist, 72, $1170-1175$.

Koster van Groos, A.F and Guggenheim, S. (1990) Dehydroxylation of $\mathrm{Ca}$ - and $\mathrm{Mg}$-exchanged montmorillonite. American Mineralogist, 74, 627-636.

Mackenzie, R.C. (1957) The Differential Thermal Investigation of Clays. Mineralogical Society, London, 456 pp.

Mackenzie, R.C. (1982) Down-to-Earth Thermal Analysis: Thermal Analysis. Wiley Heyden Ltd., Chichester, Great Britain, 25-36.

Manceau, A., Lanson, B., Drits, V.A., Chategner, D., Gates, W.P., Wu, J., Huo, D., and Stucki, J.W. (2000) Oxidationreduction mechanism of iron in dioctahedral smectites: 1. Crystal chemistry of oxidized reference nontronite. American Mineralogist, 85, 133-152.

McCarty, D. and Reynolds, R.C. (1995) Rotationally disordered illite-smectites in Paleozoic K-bentonites. Clays and Clay Minerals, 43, 271-284.

Muller, F., Drits, V.A., Besson, G. and Plançon, A. (2000) Dehydroxylation of $\mathrm{Fe}^{3+}, \mathrm{Mg}$-rich dioctahedral micas. (I) Structural transformation. Clay Minerals, 35, 491-504.

Plançon, A. (1981) Diffraction by layer structures containing different kinds of layers and stacking faults. Journal of Applied Crystallography, 14, 300-304.

Reynolds, R.C. and Thompson, C.H. (1993) Illite from the Postdam Sandstone of New York, a probable noncentrosymmetric mica structure. Clays and Clay Minerals, 41, 66-72.

Rozenson, J. and Heller-Kallai, L. (1980) Order-disorder phenomena accompanying the dehydroxylation of dioctahedral phyllosilicates. Clays and Clay Minerals, 28, 391-392.

Sakharov, B.A., Besson, G., Drits, V.A., Kameneva, M.Y., Salyn, A.N., and Smoliar, B.B. (1990) X-ray study of the nature of stacking faults in the structure of glauconites. Clay Minerals, 25, 419-435.

Tsipursky, S.I. and Drits, V.A. (1984) The distribution of octahedral cations in the 2:1 layers of dioctahedral smectites studied by oblique texture electron diffraction. Clay Minerals, 19, 177-192.

Tsipursky, S.I., Kameneva, M.Y., and Drits, V.A. (1985) Structural transformation of $\mathrm{Fe}^{3-}$-containing 2:1 dioctahedral phyllosilicates in the course of dehydroxylation. In Proceedings of the 5th Conference of the European Clay Groups, J. Konta, ed., Prague, 569-577. 
Udagawa, S., Urabe, K., and Hasu, H. (1974) The crystal structure of muscovite dehydroxylate. Japanese Association for Mineralogy, Petrology and Geology, 69, 381-389.

Wardle, R. and Brindley, G.W. (1972) The crystal structures of pyrophyllite-1Tc and of its dehydroxylate. American Mineralogist, 57, 732-750.

Zvyagin, B.B. (1967) Electron Diffraction Analysis of Clay Mineral Structures. Plenum Press, New York, $320 \mathrm{pp}$
Zvyagin, B.B., Rabotnov, V.T., Sidorenko, O.V., and Kotelnikov, D.D. (1985) Unique mica consisting of noncentrosymmetric layers. Izvestiya Akademii Nauk S.S.S.R., Seriya Geologiya, 35, 121-124. (in Russian).

E-mail of corresponding author: Fabrice.Muller@ univ-orleans.fr

(Received 5 January 2000; accepted I June 2000; Ms. 419; A.E. Stephen Altaner) 